\title{
CORRIGENDUM
}

\section{Tyler Andrew Barrett \& Sender Dovchin (eds.), Critical inquiries in the sociolinguistics of globalization. Bristol: Multilingual Matters, 2019. Pp. 200. Pb. £35. - Corrigendum}

\author{
Reviewed by Eliane Albuquerque
}

doi: 10.1017/S004740451900085X. Published online by Cambridge University Press 18 February 2020 .

In the Book Notes for Language in Society volume 49, issue 1 (Albuquerque 2020), "Kazakhstan" is misspelled three times on p. 153.

The editors apologize for this error.

\section{R E F E R E N C E}

Albuquerque, Eliane. Review of Tyler Andrew Barrett \& Sender Dovchin (eds.), Critical inquiries in the sociolinguistics of globalization. Bristol: Multilingual Matters, 2019. Pp. 200. Pb. £35. Language in Society 49(1): 153-154. doi: 10.1017/S004740451900085X. 